\title{
PRODUKSI BUBUK SINBIOTIK DARI HIDROLISATEucheuma cottonii MENGGUNAKANSPRAY DRYING
}

\section{PRODUCTION OF SYNBIOTIC POWDERS FROM HYDROLYSATES OF Eucheuma cottoniiUSING SPRAY DRYING}

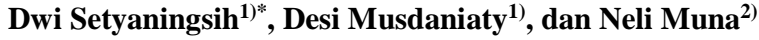 \\ ${ }^{1)}$ Departemen Teknologi Industri Pertanian, Fakultas Teknologi Pertanian, IPB \\ Kampus IPB Darmaga, PO Box 220 Bogor 16002, Indonesia \\ Email : dwisetya.sbrc@gmail.com \\ ${ }^{2)}$ Pusat Penelitian Surfaktan dan Bioenergi, LPPM, IPB
}

Makalah: Diterima 27 Juni 2019; Diperbaiki 5 Oktober 2019; Disetujui 20 Oktober 2019

\begin{abstract}
Eucheuma cottonii is red algae that contain high carbohydrates, especially carrageenan. Carrageenan is a sulfated polygalactan with 15-40\% of ester-sulfate content. It is formed by alternate units of D-galactose and 3,6-anhydro-galactose joined by $\alpha-1,3$ and $\beta$-1,4-glycosidic linkage. The galactose polymer therein can be hydrolyzed into Galactooligosaccharide (GOS)type prebiotics. Hydrolysis was done by low concentration of sulfuric acid and crude enzyme from inactivation of Vibrio algynoliticus cell broth. Combination of prebiotic and probiotic provide lactic acid bacteria $(B A L)$ as well as its food sources in the colon. The aim of this research is to know the characteristics of BALgrowth and fermentation in hydrolysateof E. cottonii and to know the best method in producing synbiotic powdersfrom BAL grown in hydrolysate. Analysis conducted include the characteristics of synbiotic powders using two types of BAL, namely Lactobacillus casei and kefir bacteria (Lactobacillus spp.). Characteristics of the two types of BAL produced during fermentation were qualified as probiotics which were amounted to more than $10^{8}$ cell $/ \mathrm{mL}, \mathrm{pH}$ value $<4.5$, and total acid $>0.2 \%$. The results showed that the number of living bacteria was higherin the method of synbiotic productions after dryingof hydrolysates followed by inoculum addition, than the method of synbiotic productions which inoculum addition was donebefore drying.
\end{abstract}

Keywords:Eucheuma cottonii, Lactobacillus casei,Lactobacillus spp.in kefir

\section{ABSTRAK}

Eucheuma cottonii merupakan rumput laut yang mengandung karbohidrat yang tinggi, khususnya karagenan. Karagenan adalah poligalaktan sulfat dengan 15-40\% kandungan sulfat ester. Tersusun dari unit yang berselingan antara D-galaktosa dan 3,6-anhidro galaktosa dengan ikatan glikosida $\alpha-1,3$ dan $\beta$-1,4-. Polimergalaktosa didalamnya dapat dihidrolisis menjadi prebiotik jenis Galaktooligosakarida (GOS). Hidrolisis dilakukan dengan asam sulfat encer dan enzim kasar dari inaktivasi broth sel Vibrio algynoliticus. Kombinasi prebiotik dengan probiotik menyediakan bakteri asam laktat (BAL) sekaligus sumber pangannya di dalamusus besar. Tujuan penelitian ini adalah mengetahui pertumbuhan dan hasil fermentasi BAL pada hidrolisat $E$. cottonii dan mendapatkan metode terbaik produksi bubuk sinbiotik dari hidrolisat tersebut. Pengujian meliputi karakteristik bubuk sinbiotik menggunakan dua jenis BAL yaitu Lactobacillus caseidan BAL kefir (Lactobacillus spp.) Karakteristik kedua jenis bakteri tersebutselama fermentas telahmemenuhi syarat untuk dapat disebut probiotik yaitu berjumlah lebih dari $10^{8} \mathrm{sel} / \mathrm{mL}$, nilai $\mathrm{pH}<4,5$, dan total asam $>0,2 \%$. Hasil penelitian menunjukkan bahwa jumlah bakteri hidup lebih banyak dalam hidrolisat pada metode pembuatan sinbiotik setelah pengeringan diikuti oleh penambahan inoculum, dibandingkan dengan metode pembuatan sinbiotik menggunakan penambahan inokulum sebelum pengeringan.

Kata kunci: Eucheuma cottonii, Lactobacillus casei, Lactobacillus spp. pada kefir

\section{PENDAHULUAN}

Salah satu jenis rumput laut yang banyak dihasilkan di Indonesia yaitu Eucheuma cottonii. Menurut data Food and Agriculture Organization (FAO) pada tahun 2015, produksi E.cottonii Indonesia menempati urutan pertama di dunia yaitu sebanyak 8,3 juta ton. E.cottonii mengandung karbohidrat yang tinggi, yaitu mencapai 73,81\% (Liem, 2013). Rumput laut mengandung sejumlah besar polisakarida. Polisakarida tersebut antara lain alginat dari rumput laut coklat, karagenan dan agar dari rumput laut merah dan beberapa polisakarida minor lainnya yang ditemukan pada rumput laut hijau (Anggadiredja et al., 2006). Kebanyakan dari polisakarida tersebut tidak dapat dicerna di dalam usus manusia, sehingga dapat berfungsi sebagai serat makanan (dietary fiber). Kandungan serat rumput laut dapat mencapai $30-40 \%$ berat kering dengan persentase lebih besar pada serat larut air. Kandungan serat larut air rumput laut jauh lebih 
tinggi dibanding dengan tumbuhan darat yang hanya mencapai sekitar $15 \%$ berat kering.

Oligosakarida merupakan karbohidrat yang mempunyai berat molekul rendah. Oligosakarida non-digestible (NDO) berada pada kelompok diantara polisakarida dan gula sederhana. Berdasarkan IUPAC, oligosakarida merupakan sakarida yang mengandung antara 3-10 rantai gula. Musatto dan Mancilha (2007) menyebutkan oligosakarida mengandung 3-19 unit monosakarida. Oligosakarida bersifat larut dalam air dan mempunyai tingkat kemanisan 0,3-0,6 kali sukrosa. Beberapa golongan oligosakarida yang populer, antara lain frukto-oligosakarida, galaktooligosakarida, malto-oligosakarida, laktulosa, rafinosa dan xylo-oligosakarida.Golongan tersebut terbagi berdasarkan perbedaan struktur molekulnya. Beberapa manfaat dari fermentasi NDO untuk kesehatan antara lain adalah dapat memodifikasi mikroflora kolon karena oligosakarida dapat berfungsi sebagai substrat untuk pertumbuhan bakteri baik, khususnya Bifidobacteria, mengurangi $\mathrm{pH}$ usus, produksi nutrien, seperti vitamin B kompleks (B1, B2, B6 dan B12) dan asam folat, melindungi dari resiko terkena infeksi pada jalur pencernaan dan respirasi pada tubuh manusia dan meningkatkan penyerapan berbagai macam mineral, seperti zat besi, kalsium dan magnesium (Musatto dan Mancilha. 2007). Oleh karena NDO dapat memicu berkembangnya bakteri baik pada sistem pencernaan dan bermanfaat bagi kesehatan, maka oligosakarida juga dapat diklasifikasikan sebagai prebiotik dan pangan fungsional.

Hidrolisis karagenan dengan bantuan enzim $\square$-karagenase menghasilkan prebiotik jenis galaktooligosakarida (GOS) yang dapat dimetabolisme oleh BAL dalamusus besar, karena enzim $\alpha$-galaktosidase dan $\beta$-galaktosidase yang dihasilkannya mampu menghidrolisis GOS. Probiotik yang ditumbuhkan pada media yang diperkaya prebiotik di dalamnya, memiliki efek yang lebih baik bagi kesehatan manusia. Probiotik adalah makanan suplemen berupa mikroba hidup yang menguntungkan manusia khususnya dalam keseimbangan mikroflora usus. Probiotik secara langsung mampu membantu mikroflora yang berada di saluran pencernaan guna menghambat bakteri patogen yang menggangu saluran pencernaan. Beberapa manfaat dari preobiotik, antara lain mencegah diare, meningkatkan kekebalan tubuh, bermanfaat bagi penderita lactose intolerance, menurunkan resiko alergi dan penyakit kanker, serta melancarkan siklus pencernaan (Vasudha dan Mishra, 2013).

Mekanisme probiotik hingga dapat meningkatkan kesehatan tubuh adalah dengan cara memproduksi senyawa antimikroba seperti asam laktat, asam asetat, karbondioksida, hidrogen peroksida, bakteriosin, dan senyawa penghambat pertumbuhan bakteri patogen lainnya. Probiotik juga unggul dalam kompetisi penyerapan nutrien dan sisi penempelan pada sel epitel usus dan menstimulasi sistim imunitas serta mampu mengubah aktivitas metabolisme mikroba dalam saluran pencernaan. Sifat-sifat yang dimiliki oleh probiotik adalah aman untuk manusia, mampu melewati usus dalam keadaan hidup dan bermanfaat bagi kesehatan antara lain mencegah diare, meningkatkan daya tahan tubuh dan mengurangi racun dalam usus (Antarini, 2011).

Bakteri asam laktat seperti Lactobacillus dan Bifidobacteria secara alami terdapat dalam saluran pencernaan manusia dan hewan, dan dalam produk makanan fermentasi seperti yogurt, keju, berbagai produk salami, pikel buah dan sayuran. Lactobacillus berbentuk batang terdapat dalam bentuk tunggal maupun rantai pendek atau panjang, bersifat thermofil, thermodurik, memproduksi gas seperti $\mathrm{CO}_{2}, \mathrm{H}_{2} \mathrm{~S}, \mathrm{H}_{2}$ selama metabolisme, termasuk dalam bakteri anaerob fakultatif. Lactobacillus menggunakan karbohidrat sebagai sumber energi dan memproduksi asam laktat sebagai produk utama dari hasil metabolismenya (Ray, 2005).

Hidrolisat E.cottoniidalam bentuk bubuk dimaksudkan untuk memperpanjang masa simpan produk dan memudahkan aplikasinya. Proses pengeringan dilakukan menggunakan metode spray drying (pengeringan semprot). Spray drying merupakan teknik enkapsulasi yang banyak digunakan di industri pangan karena ekonomis, fleksibel dan dapat dilakukan secara kontinyu. Bahan yang dimasukkan ke dalam spray drying berada dalam bentuk emulsi dengan bahan dinding berupa maltodekstrin, gum arab, chitosan, kasein maupun susu skim. Sementara bahan inti yang akan disalut dapat berupa mikroba, ekstrakatau komponen flavor. Pada proses spray drying, cairan disemprotkan ke dalam aliran udara panas sehingga air dalam droplet menguap dengan cepat meninggalkan bahan kering. Bahan kering dipisahkan dari udara dengan separator. Walaupun suhu udara yang masuk ruang pengering cukup tinggi, namun kecepatan pengeringan yang tinggi dapat menghindarkan bahan dari pemanasan yang berlebihan dan tidak ada kontak bahan basah dengan media panas. Aliran uap air dari bahan akan menghambat difusi oksigen ke dalam bahan sehingga oksidasi yang terjadi selama pengeringan dapat diminimalkan. Tujuan penelitian iniadalah untuk mengetahui karakteristik hasil fermentasi bakteri asam laktat pada hidrolisat $E$. cottonii, serta mendapatkan metode produksi bubuk sinbiotik menggunakan spray dryingdari hidrolisat $E$. cottonii dan bakteri $L$. casei dan bakteri asam laktat kefir (Lactobacillus sp).

\section{METODE PENELITIAN}

\section{Tahapan Penelitian}

Persiapan Starter

Kultur yang digunakan yaitu L.caseidan BAL kefir. Masing-masing kultur BAL diinkubasi 
sebanyak $1 \mathrm{~mL}$ kedalam $9 \mathrm{~mL}$ media cair deMan Rogosa Sharpe (MRS). Inkubasi dilakukan pada suhu $37{ }^{\circ} \mathrm{C}$ selama 48 jam sebagai kultur stok. Sebanyak $1 \mathrm{~mL}$ kultur diinkubasi lagi pada media waktu dan suhu yang sama untuk digunakan sebagai kultur intermediate. Sebanyak $1 \mathrm{~mL}$ kultur intermediate diinkubasi sesuai fase awal eksponensial masing-masing bakteri sebelum dimasukkan pada hidrolisatE.cottonii.

\section{$\underline{\text { Persiapan Sel Inaktif Vibrio }}$}

Hidrolisis dilakukan menggunakan enzim dari kultur inaktif Vibrio alginolyticus. Kultur inaktif diproduksi dengan menginokulasi isolat V.alginolyticus yang telah diremajakan (propagasi) sebanyak satu ose penuh ke dalam $100 \mathrm{~mL}$ media karagenan. Media padat karagenan terbuat dari 30 gram karagenan, $30 \mathrm{~g} \mathrm{NaCl}$, pepton, yeast extract dan campuran mineral yang dilarutkan dalam 1 liter air destilata. Media disterilisasi dalam autoklaf pada suhu $121^{\circ} \mathrm{C}$, tekanan 1 atm selama 15 menit. Inkubasi $V$. alginolyticus dilakukan selama 10 jam dalam penangas air suhu $35^{\circ} \mathrm{C}$ dan kecepatan agitasi $100 \mathrm{rpm}$. Kultur V.alginolyticus kemudian disonikasi selama 5 menit pada suhu $4^{\circ} \mathrm{C}$ dan frekuensi $50 \mathrm{~Hz}$. Selanjutnya kultur disentrifugasi selama 15 menit dan supernatan diambil. Selanjutnya digunakan sebanyak $20 \%$ ke dalam media rumput laut.

\section{Persiapan Media Hidrolisat Fermentasi}

Sebanyak $8 \mathrm{~g}$ E.cottonii dimasukkan ke dalam Erlenmeyer, kemudian ditambah 0,6 mL $\mathrm{H}_{2} \mathrm{SO}_{4} 3 \%$ dan $199,4 \mathrm{~mL}$ akuades. Campuran ini diotoklaf selama 30 menit pada suhu $121^{\circ} \mathrm{C}$. Selanjutnya dinetralkan dengan kapur tohor hingga $\mathrm{pH}$ 7. Lebih lanjut ditambah $40 \mathrm{~mL}$ kultur inaktif dan diinkubasi dalam penangas air suhu $30^{\circ} \mathrm{C}$ selama 72 jam. Reaksi melalui pemanasan pada suhu $90^{\circ} \mathrm{C}$ selama 15 menit pada alat yang sama.

\section{Spray Drying Bubuk Sinbiotik}

Hidrolisat E. cottonii digunakan untuk bahan pembuatan bubuk sinbiotik. Metode yang digunakan meliputi pembuatan sinbiotik sebelum pengeringan dan pembuatan sinbiotik setelah pengeringan. Pada pembuatan sinbiotik sebelum pengeringan, hidrolisat $E$. cottonii dicampur dengan maltodekstrin $2 \%$ volume hidrolisat, kemudian ditambah $0,5 \%$ yeast extract dan $1 \%$ pepton (b/v) danpanaskan pada suhu $90^{\circ} \mathrm{C}$ dalam penangas air. Selanjutnya ditambahinokulum BAL sebanyak $10 \%$ dari volume hidrolisat dan diinkubasi pada suhu $30^{\circ} \mathrm{C}$ selama 48 jam. Setelah diinkubasi dilanjutkan dengan pengeringan.

Pada pembuatan sinbiotik setelah pengeringan, hidrolisat E. Cottonii yang ditambah maltodekstrin $2 \%$ dari volume hidrolisat dikeringkan terlebih dahulu sehingga dihasilkan bubuk prebiotik, kemudian ditambahkan $0,5 \%$ yeast extract dan $1 \%$ pepton (b/b) dan $1 \mathrm{~mL}$ akuades streril $(0,1 \%$ dalam $10 \mathrm{~g}$ bubuk prebiotik), lalu diaduk rata. Media selanjutnya ditambah10\% inokulum BALdan diinkubasi pada suhu $37{ }^{\circ} \mathrm{C}$ selama 48 jam.

Pengamatan mikroba dilakukan secara langsung menggunakan alat hemasitometer.Pengamatan dalam membedakan sel mati dan hidup dilakukan dengan penambahan warna yang berbeda.Satu tetes sampel diteteskan di tengah alat hemasitometer.Biarkan hingga tersebar rata, lalu tutup dengan kaca penutup hemasitometer. Perhitungan dilakukan dengan kotak-kotak skala dimana setiap ukuran skala seluas $1 \mathrm{~mm}^{2}$ terdapat 25 buah kotak besar dengan luas $0.04 \mathrm{~mm}^{2}$ dan setiap kotak besar terdiridari 16 kotak kecil. Alat hemasitometer digunakan dibawah mikroskop yang sisinya mempunyai ukuran $0.05 \mathrm{~mm}$ dengan tebal $0.1 \mathrm{~mm}$. Jumlah sel per $\mathrm{ml}$ sampel dapat dihitung sebagai berikut :

Jumlah sel per $\mathrm{mL}$ sampel $=$ Jumlah Sel per Kotak Besar x $1,25 \times 10^{6}$

\section{HASIL DAN PEMBAHASAN}

\section{Karakteristik HidrolisatE. cottonii}

Fermentasi pendahuluan dilakukakan dengan memodifikasi penelitian Ridho'ah (2017). Fermentasi yang dilakukan oleh Ridho'ah (2017) adalah menggunakan $18 \mathrm{~g}$ E. cottonii kering dan ditambah $\mathrm{H}_{2} \mathrm{SO}_{4} 3 \%$ sebanyak $0,5 \mathrm{~mL}, 20 \mathrm{~mL}$ kultur inaktif serta $5 \%$ inokulum BAL pada hidrolisat tanpa menambah nutrisi apapun difermentasi pada suhu $37^{\circ} \mathrm{C}$ selama 72 jam. Tujuan fermentasi ini adalah untuk mengetahui kemampuan pertumbuhan BAL pada hidrolisat E.cottonii dengan melihat karakteristik hidrolisat yang dihasilkan.

Hidrolisis polisakarida rumput laut menggunakan asam sangat dipengaruhi oleh konsentrasi asam dan substrat yang digunakan, suhu dan lama waktu hidrolisis. Berdasarkan penelitian yang dilakukan oleh Zelfi (2016), konsentrasi substrat E.cottonii dan asam yang terbaik yaitu sebanyak $12 \%$ substrat dengan $3 \%$ asam $\mathrm{H}_{2} \mathrm{SO}_{4}$. Jika penambahan konsentrasi asam tidak tepat, maka akan terbentuk senyawa inhibitor mikroba pada rumput laut, seperti hydroxymethyl fulfural (HMF) dan asam levulinat yang dapat menghambat produktivitas fermentasi mikroorganisme. Hidrolisis E. cottonii dengan $\mathrm{H}_{2} \mathrm{SO}_{4}$ dalam hal ini sebagai pretreatment yang bertujuan untuk menghidrolisis sebagian polisakarida sehingga substrat tidak mudah berubah menjadi struktur gel, dan memudahkan penetrasi enzim ke dalam struktur polisakarida.

Pembentukan gel pada hidrolisat rumput laut disebabkan karena 3,6- anhidrogalaktosa dalam polisakarida E. cottonii memiliki kemampuan untuk berubah menjadi gel setelah dipanaskan. Saat terjadi penurunan suhu, polimer akan membentuk struktur double helix (pilinan ganda) dan apabila suhu semakin turun polimer ini akan terikat silang secara 
kuat dan semakin bertambahnya struktur helix yang bertanggung jawab terhadap terbentuknya gel yang semakin kuat. Struktur larutan yang berbentuk gel akan mempersulit penetrasi enzim dalam mengikat substrat, sehingga aktivitas enzim dalam menghasilkan gula pereduksi akan terhambat.

Setelah dihidrolisis menggunakan asam, hidrolisat hasil hidrolisis rumput laut E. cottonii ditambahkan kultur $V$. alginolyticus yang telah diinaktivasi dengan metode ultrasonikasi. Hidrolisis menggunakan kultur inaktif dilakukan dalam waterbath pada suhu $35^{\circ} \mathrm{C}$ selama 30 menit. Penentuan jenis kultur dan perlakuan telah dilakuan pada tahapan penelitian sebelumnya. Inaktivasi dengan sonikasi bertujuan untuk memecah dinding sel dan mengeluarkan enzim intraselular pada kultur $V$. alginolyticus. Pemecahan dinding sel dengan metode sonikasi terjadi akibat penggunaan frekuensi gelombang suara ultrasonik yang besar. Gelombang suara menyebabkan terjadinya proses kavitasi yaitu terbentuknya gelembung gas yang bergerak dengan kecepatan tinggi sehingga terbentuk energi mekanik yang menyebabkan dinding sel pecah (Chaplin dan Buckle, 1990). Kultur tanpa sonikasi tidak mengandung unsur enzim intraseluler yang masih terdapat dalam dinding sel bakteri. Adanya proses sonikasi yang mengeluarkan enzim intraseluler mengakibatkan terakumulasinya enzim intraseluler dan ekstraseluler dalam media starter, sehingga adanya peningkatan aktivitas enzim. .

Pada penelitian ini, dilakukan modifikasi dengan mengurangi jumlah padatan E.cottonii yaitu menggunakan $8 \mathrm{~g}$ kering dan ditambah 0,6 mL asam $\mathrm{H}_{2} \mathrm{SO}_{4} 3 \%$ dan $40 \mathrm{~mL}$ kultur inaktif $V$. alginolyticus. Selanjutnya hidrolisat difermentasi dengan menambahkan $10 \%$ inokulum Lactobacillus casei yang telah diremajakan pada suhu $37^{\circ} \mathrm{C}$ selama 72 jam dalam $100 \mathrm{~mL}$ media MRS (Man, Rogosa and Sharpe) Broth. Bakteri jenis ini dapat memfermentasi beberapa golongan karbohidrat seperti arabinose, melibiosa, xylose, laktosa, glukosa, maltose, fruktosa, dan galaktosa untuk metabolisme dan memproduksi energi (ATP) (Kailasapathy et al., 2011).

Hidrolisat yang dihasilkan diamati karakteristik gula pereduksi, total gula, $\mathrm{pH}$, dan jumlah sel bakteri yang tumbuh. Karakteristik hidrolisat disajikan pada Tabel 1. Hasil menunjukkan bahwa modifikasi hidrolisisdengan total padatan yang lebih rendah menghasilkan kadar gula pereduksi dan total gula yang lebih tinggi. Secara visual hidrolisat lebih encer sehingga mudah diproses. Hal ini menunjukkan pemecahan polisakarida karagenan oleh enzim hidrolitik dari kultur inaktif $V$. alginolyticus mampu menghasilkan oligosakarida rantai pendek, sehingga diharapkan dapat lebih mudah difermentasi oleh L.casei.

Tabel 1. Karakteristik hidrolisat E. cottonii sebelum fermentasi L.casei

\begin{tabular}{|c|c|c|}
\hline Jenis Uji & $\begin{array}{c}\text { Hasil } \\
\text { Penelitian }\end{array}$ & $\begin{array}{c}\text { Ridho'ah } \\
2017\end{array}$ \\
\hline $\begin{array}{l}\text { Gula pereduksi (g } \\
100 \mathrm{~mL}^{-1} \text { ) }\end{array}$ & $0,315 \pm 0,02$ & $0,206 \pm 0,028$ \\
\hline Total gula (g $\left.100 \mathrm{~mL}^{-1}\right)$ & $7,200 \pm 1,50$ & $6,495 \pm 0,630$ \\
\hline $\mathrm{pH}$ & $4,815 \pm 0,077$ & $5,025 \pm 0,148$ \\
\hline Total padatan & $2 \%$ & $6 \%$ \\
\hline
\end{tabular}

Kemampuan Pertumbuhan L. casei pada Hidrolisat $E$. cottonii

Fermentasi dilakukan menggunakan 10\% inokulum L.casei dalam hidrolisat E. Cottonii yang ditambah $0,5 \%$ yeast extract dan $1 \%$ pepton pada suhu $37^{\circ} \mathrm{C}$ selama 72 jam. Kandungan hidrolisat sebelum dan sesudah fermentasi disajikan pada Tabel 2.

Tabel 2 menunjukkan terjadi kenaikan jumlah bakteri yang signifikan dari $18,75 \times 10^{8}$ $\mathrm{sel} / \mathrm{mL}$ menjadi $27,15 \times 10^{8} \mathrm{sel} / \mathrm{mL}$. Hasil ini menunjukkan bahwa jumlah L.casei yang dihasilkan telah memenuhi kriteria probiotik menurut Heller (2001) yaitu diatas $10^{8} \mathrm{sel} / \mathrm{mL}$ produk.Pertumbuhan L.casei pada media hidrolisat E. cottonii dapat dideteksi dari penurunan nilai gula pereduksi dan pH. Gula pereduksi pada hidrolisat mengalami penurunan yang signifikan dari $0,32 \mathrm{~g} \mathrm{~mL}^{-1}$ menjadi $0,16 \mathrm{~g} \mathrm{~mL}^{-1}$ atau hanya dikonsumsi sebesar $0,16 \mathrm{~g}$ $\mathrm{mL}^{-1}$. Nilai $\mathrm{pH}$ mengalami penurunan yang signifikan dari 4,82 menjadi 4,43.

Tampak bahwa aktivitas L.casei berlangsung dengan baik pada hidrolisat dibuktikan dengan tingginya konsumsi gula pereduksi selama fermentasi dan rendahnya nilai $\mathrm{pH}$ identik dengan produk hasil fermentasi berupa asam-asam organik. Menurut Oberman (1985), peningkatan jumlah bakteri menyebabkan peningkatan kebutuhan senyawa yang dirombak menjadi asam laktat.

Tabel 2. Kandungan hidrolisat sebelum dan sesudah fermentasi L. casei

\begin{tabular}{lcc}
\hline \multicolumn{1}{c}{ Parameter } & Sebelum fermentasi & Setelah fermentasi \\
\hline Gula pereduksi $(\mathrm{g} 100 / \mathrm{mL})$ & $0,32 \pm 0,02^{\mathrm{a}}$ & $0,16 \pm 0,01^{\mathrm{b}}$ \\
Total gula $(\mathrm{g} / 100 \mathrm{~mL})$ & $7,20 \pm 1,56^{\mathrm{a}}$ & $12,40 \pm 0,21^{\mathrm{a}}$ \\
$\mathrm{pH}$ & $4,82 \pm 0,07^{\mathrm{a}}$ & $4,43 \pm 0,03^{\mathrm{b}}$ \\
Jumlah sel bakteri $(\mathrm{sel} / \mathrm{mL})$ & $(18,75 \pm 1,06) \times 10^{8 \mathrm{a}}$ & $(27,15 \pm 0,21) \times 10^{8 \mathrm{~b}}$ \\
\hline
\end{tabular}

*Angka pada kolom yang sama yang diikuti oleh huruf yang tidak sama berbeda nyata pada taraf uji $5 \%$ (uji $\mathrm{T}$ ) 
Semakin tinggi total BAL maka penggunaan gula sebagai substrat juga semakin besar. Total gula pada hidrolisat mengalami kenaikan yang tidak signifikan dari $7,20 \mathrm{~g} / \mathrm{mL}$ menjadi $12,40 \mathrm{~g} / \mathrm{mL}$. Kenaikan total gula dapat disebabkan oleh belum banyaknya hidrolis padatan dan serat pangan pada hidrolisat E.cottonii sebelum fermentasi atau selama hidrolisis berlangsung. Menurut Fardiaz (1992), adanya pengadukan saat penambahan bahan menyebabkan oksigen masuk ke dalam hidrolisat dan membentuk reaksi flavo protein dengan $\mathrm{O}_{2}$ yang tidak dapat dipecah oleh BAL.

\section{Karakteristik Hasil Fermentasi L.casei dan Kefir pada Hidrolisat}

Gula pereduksi merupakan golongan gula yang memiliki kemampuan untuk mereduksi senyawa-senyawa penerima elektron karena adanya gugus aldehid dan keton bebas. Hasil menunjukkan bahwa pada masing-masing BAL terdapat perbedaan signifikan pada jumlah gula pereduksi pada saat sebelum dan sesudah fermentasi dilihat dari Tabel 3. Perbedaan yang signifikan ini membuktikan bahwa gula pereduksi dikonsumsi oleh bakteri dalam jumlah besar selama fermentasi. Struktur gula yang sederhana membuat BAL mudah memetabolisme menghasilkan energi pertumbuhan. Selain itu, BAL kefir mengkonsumsi lebih banyak gula pereduksi dibandingkan dengan L.casei, namun konsumsi masing-masing BAL tersebut tidak berbeda signifikan.

Total gula merupakan campuran gula pereduksi dan non reduksi hasil hidrolisis pati. Tampak bahwa total gula dalam hidrolisat dikonsumsi dalam jumlah yang berbeda oleh kedua jenis BAL tersebut. Konsumsi gula yang tinggi ditunjukkan oleh L.casei yaitu $42,45 \mathrm{~g}$, sedangkan konsumsi gula oleh BAL kefir hanya 11,74 g. Total gula di awal fermentasi berkisar $6,11-7,20 \mathrm{~g}$, sedangkan gula pereduksi berkisar 0,315-0,317 g. Total gula yang tersisa setelah fermentasi, kemungkinan sebagian besar berupa galakto oligosakarida yang dimanfaatkan sebagai sumber makanan (prebiotik) untuk pertumbuhan BAL di kolon.
Penggunaan gula pereduksi oleh BAL menghasilkan beberapa produk asam organik diantaranya asam laktat, asam asetat, asam oksalat, dan sitrat. Asam-asam organic hasil fermentasi inilah yang mempengaruhi nilai $\mathrm{pH}$ hidrolisat. Semakin banyak kandungan asam organik, semakin rendah nilai pH (Zubaidah, 2006). Tabel 3 menunjukkan bahwa kedua jenis BAL menghasilkan $\mathrm{pH}$ yang berbeda. Nilai pH masing-masing BAL berbeda nyata antara sebelum dan setelah fermentasi.Nilai pH BAL mengalami penurunan yang signifikan. Penurunan $\mathrm{pH}$ mengindikasi bertambahnya asamasam organik selama fermentasi. Menurut Leroy dan Vuyst (2004), BAL umumnya menghasilkan asam laktat dan asam organik lainnya dari hasil fermentasi gula sebagai substratnya. Asam yang dihasilkan tersebut menurunkan $\mathrm{pH}$ dan menimbulkan rasa asam. Masing-masing BAL tersebut juga telah memenuhi kriteria $\mathrm{pH}$ yang bersifat bakteriosidal menurut Rachmawati et al. (2005) yaitu $\mathrm{pH}$ di bawah 4,5.

Yusmarini et al. (2010) menyatakan bahwa hasil metabolisme gula yang digunakan oleh bakteri asam laktat (Lactobacillus) menghasilkan energi untuk pertumbuhannya dan menghasilkan produk metabolit berupa asam organik. Konsumsi gula berbanding lurus dengan jumlah metabolit yang dihasilkan.Semakin besar konsumsi gula oleh mikroba, maka asam yang dihasilkan juga semakin besar. Berdasarkan Tabel 3, diketahui bahwa peningkatan total asam masing-masing BAL berbeda signifikan. Peningkatan yang lebih tinggi terjadi pada fermentasi menggunakan BAL kefir yang mampu meningkatkan total asam sebesar $0,13 \%$, sedangkan L.casei hanya meningkatkan total asam sebesar $0,09 \%$. Total asam masing-masing BAL memiliki perbedaan yang signifikan sebelum dan sesudah fermentasi.Hal ini membuktikan bahwa kedua jenis BAL mampu menghasilkan asam organik selama fermentasi. Tingginya kenaikan total asam yang dihasilkan oleh masing-masing BAL ditunjukkan oleh konsumsi gula yang juga tinggi selama fermentasi.

Tabel 3. Hasil fermentasi bakteriL.casei dan kefir pada hidrolisat E. cottonii

\begin{tabular}{lccc}
\hline \multirow{2}{*}{ Parameter } & \multirow{2}{*}{ Fermentasi } & \multicolumn{2}{c}{ Jenis bakteri } \\
\cline { 3 - 4 } Gula pereduksi $(\mathrm{g} / 100 \mathrm{~mL})$ & Sebelum & $0,315 \pm 0,02$ & BAL kefir \\
& Sesudah & $0,16 \pm 0,01$ & $0,317 \pm 0,02$ \\
\multirow{2}{*}{ Total gula $(\mathrm{g} / 100 \mathrm{~mL})$} & Sebelum & $7,20 \pm 1,56$ & $0,26 \pm 0,01$ \\
& Sesudah & $12,45 \pm 0,21$ & $6,11 \pm 0,98$ \\
pH & Sebelum & $4,82 \pm 0,07$ & $11,74 \pm 0,09$ \\
& Sesudah & $4,43 \pm 0,03$ & $4,76 \pm 0,16$ \\
Total Asam & Sebelum & $0,07 \pm 0,01$ & $4,41 \pm 0,13$ \\
& Sesudah & $0,20 \pm 0,02$ & $0,15 \pm 0,02$ \\
& & & $0,24 \pm 0,02$ \\
\hline
\end{tabular}


Total asam hasil fermentasi berkisar antara 0,20-0,24\%. Konsentrasi ini telah sesuai dengan batas minimum asam organik yang memiliki aktivitas penghambatan terhadap bakteri patogen menurut Ray dan Daescher (1992) yaitu di atas 0,2\%. Permatasari et al. (2018) melakukan hidrolisis dengan cara yang sama dengan perlakuan penyaringan, pengendapan dan tanpa perlakuan setelah hidrolisis, selanjutnya hidrolisat diinokulasi dengan Bifidobacterium longum. Hasil yang diperoleh menunjukkan hidrolisat tanpa perlakuan memiliki karakteristik terbaik dengan nilai kadar gula reduksi sebesar $0,37 \%$, total gula $2,88 \%, \mathrm{pH}$ 4.95 , total asam $0,15 \%$, total BAL $62 \times 10^{7} \mathrm{CFU} / \mathrm{mL}$, kadar galaktosa dan GOS masing-masing sebesar $0,14 \%$ dan $1,18 \%$.

\section{Metode Produksi Bubuk Sinbiotik dengan Spray Drying}

Spray drying merupakan metode komersial yang secara luas digunakan untuk mengubah produk berbentuk cair menjadi bentuk bubuk. Pengeringan kultur BAL menggunakan metode spray drying dipilih karena sederhana dan dapat diselesaikan dalam waktu relative singkat. Maltod ekstrin sebanyak $2 \%$ ditambahkan sebagai bahan pengisi atau filler sehingga dapat meningkatkan viskositas, mengurangi kehilangan volume setelah pengeringan, meningkatkan kelarutan dan membantu penyebaran produk yang dikeringkan sehingga tidak lengket atau menempel pada permukaan dinding mesin spray dryer (Kennedy, 1995).

Dalam memproduksi bubuk sinbiotik, hidrolisat E. Cottonii diperlakukan dengan metode yang berbeda. Metode yang digunakan yaitu pembuatan sinbiotik sebelum pengeringan dan pembuatan sinbiotik setelah pengeringan spray drying. Metode pengeringan hidrolisat E. cottonii terlebih dahulu dan lebih lanjutnya ditambah BAL menghasilkan produk sinbiotik yang memiliki jumlah sel bakteri yang lebih tinggi. Pada metode pembuatan sinbiotik sebelum pengeringan, jumlah sel diamati saat sebelum dan sesudah spray drying. Pada metode pembuatan sinbiotik setelah pengeringan, jumlah sel bakteri diamati saat sebelum dan sesudah diinkubasi pada suhu $30^{\circ} \mathrm{C}$.

Berdasarkan Tabel 4 diketahui jumlah sel bakteri pada bubuk sinbiotik dengan metode sebelum pengeringan, bakteri L.casei dan BAL kefir mengalami penurunan pada saat sebelum dan sesudah dilakukan pengeringan. Pada metode pembuatan sinbiotik setelah pengeringan hidrolisat, L. casei mengalami kenaikan jumlah dan BAL kefir mengalami penurunan. Namun, kedua metode tersebut menunjukkan bahwa metode pembuatan sinbiotik setelah pengeringan hidrolisat memiliki jumlah bakteri lebih tinggi dibandingkan metode pembuatan sinbiotik sebelum pengeringan. Hal ini disebabkan pada pembuatan sinbiotik sebelum pengeringan hidrolisat terjadi kontak langsung antara spray dryer dengan mikroba. Menurut Anal dan Singh (2007), mortalitas bakteri pada proses spray drying terjadi karena stress panas dan dehidrasi yang dialami sehingga menyebabkan kerusakan membran sel dan ikatan proteinnya. Kedua metode yang digunakan masih memenuhi persyaratan produk bubuk sinbiotik, yaitu jumlah sel masing-masing BAL lebih dari $10^{8} \mathrm{sel} / \mathrm{mL}$. Menurut Purwijantiningsih (2007), syarat minimum produk probiotik yakni harus mengandung lebih dari $10^{8} \mathrm{sel}$ bakteri probiotik per mL. Metode yang dijadikan pilihan dalam memproduksi bubuk sinbiotik dari $E$. cottonii adalah metode pembuatan sinbiotik setelah pengeringan hidrolisat diikuti dengan penambahan inokulum BAL. Hal ini dikarenakan hidrolisat tidak terjadi kontak langsung antara spray dryer dengan mikroba sehingga hidrolisat memiliki jumlah bakteri yang lebih tinggi. Warna hidrolisat hasil spray drying tampak agak putih dan tekstur halus, namun bersifat higroskopis. Warna akan berubah menjadi kekuningan dan lengket setelah beberapa hari. Permatasari et al. (2018) melakukan spray drying hidrolisat $E$. cottonii yang telah ditumbuhkan $B$. longum dengan 20\% maltodekstrin. Dihasilkan bubuk sinbiotik berwarna putih dan halus serta memiliki nilai kelarutan $0,63 \%$ dalam akuades.

\section{KESIMPULAN DAN SARAN}

\section{Kesimpulan}

Penggunaan L. casei sp.dan BAL kefir (Lactobacillus sp.dan Streptococcus sp) dalam pembuatan sinbiotik mampu menghasilkan bubuk sinbiotik. Jumlah BAL hidup pada metode pengeringan hidrolisat diikuti dengan penambahan BAL, lebih banyak dibandingkan metode penambahan BAL sebelum pengeringan. Metode terpilih memproduksi bubuk sinbiotik dari hidrolisat E.cottonii adalah metode penambahan BAL setelah pengeringan hidrolisat.

Tabel 4. Jumlah sel bakteri (sel/ml)pada bubuk sinbiotik dengan dua metode

\begin{tabular}{cccc}
\hline Metode & Tahap & \multicolumn{2}{c}{ Jumlah bakteri (x10 $\mathbf{s e l} / \mathbf{m L})$} \\
\cline { 3 - 4 } & s. casei & BAL Kefir \\
\hline Penambahan BAL - & sebelum spray drying & 25,60 & 26,90 \\
Spray drying & sesudah spray drying & 7,27 & 6,87 \\
Spray drying - & sebelum penambahan & 17,4 & 14,1 \\
Penambahan BAL & sesudah penambahan & 21,0 & 11,0 \\
\hline
\end{tabular}


Saran

Perlu dilakukan pengujian kadar GOS padab ubuk prebiotik dan perbaikan metode fermentasi pendahuluan agar polisakarida yang terbentuk terhidrolisis secara sempurna. Pembuatan bubuk spray drying perlu diteliti dengan berbagai konsentrasi maltodekstrin untuk menghasilkan kestabilan tekstur yang lebih baik.

\section{DAFTAR PUSTAKA}

Anggadiredja TJ, Zatnika A, Purwoto H dan Istini S. 2006. Rumput Laut. Penebar Swadaya. Jakarta.

Antarini AAN. 2011. Sinbiotik antara prebiotik dan probiotik. Jurnal Ilmu Gizi 2 (2): 148-155.

[FAO] Food and Agriculture Organization. 2015. Global Aquaculture Production. http://www.fao.org/figis/servlet/SQServlet? file=/work/FIGIS/prod/webappgis/temp/hq p_5639775904334991979.xml\&outtype $=\mathrm{ht}$ ml\&xp_check=1:13001:[2 juni 2018].

Fardiaz S. 1992. Mikrobiologi Pangan 1. Jakarta (ID):Gramedia Pustaka Utama.

Firmansyah A. 2001. Terapi probiotik dan prebiotik pada penyakit saluran cerna anak. Sari Pediatri. 2(4): 210-214.

Gourbeyre P, Denery S, dan Bodinier M. 2010. Probiotics, prebiotics and synbiotics: impact on the gut immune system and allergic reactions. Journal Leokocyte Biology. 89(5) : 685-695.

Heller KJ. 2001. Probiotic bacteria in fermented foods: product characteristics and starter organism. Clinical Nutrition. 73(2): 374379.

Kennedy. 1995. Maltodextrins. London : Handbook of Starch Hydrolysis Product and Their Derivatives.

Leroy F dan Vuyst LD. 2004. Lactic acid bacteria as functional starter cultures for the food fermentation industry.Trends in Food Science and Technology 15: 6768.
Liem ZA. 2013. Kandungan proksimat dan aktivitas antioksidan rumput laut merah (Eucheuma cottonii) di perairan Kupang Barat [tesis]. Salatiga (ID): Universitas Kristen Satya Wacana.

Mussatto SI dan Mancilha IM. 2007. Non-Digestible Oligosaccharides: A Review. Carbohydrate Polymers. 68 : 587-597

Oberman H. 1985. Fermented Milks. London : Elsevier Applied Science Publisher.

Permatasari VR, Setyaningsih D, dan Haditjaroko L. 2018. Hidrolisis rumput laut Eucheuma cottonii menggunakan asam sulfat. Jurnal Teknologi Pertanian. 19 (2): 85-94

Purwijantiningsih E. 2007. Pengaruh jenis prebiotik terhadap kualitas yogurt probiotik. Biota. 12(3) : 177-185.

Rachmawati I, Suranto, dan Setyaningsih R. 2005. Uji antibakteri bakteri asam laktat asal asinan sawi terhadap bakteri patogen.Bioteknologi 2(2) : 43-48.

Ray B dan Daeschel M. 1992. Food biopreservative of microbial origin. Boca Raton : CRC Pr.

Ray B. 2005. Fundamental Food Microbiology. $3^{\text {rd }}$ ed. Florida: CRC Press LLC

Ridho'ah T. 2017. Karakteristik probiotik Bifidobacterium longum dan Lactobacillus casei pada hidrolisat Eucheuma cottonii [skripsi]. Bogor (ID) : Institut Pertanian Bogor.

Vasudha S dan Mishra HN. 2013. Non dairy probiotic beverages. International Food Research Journal. 20(1): 7-15.

Yusmarini RI, Utami T, Marsono Y. 2010. Aktivitas proteolitik bakteri asam laktat dalam fermentasi susu kedelai. Teknologi dan Industri Pangan.21(2).

Zubaidah E. 2006. Pengembangan pangan probiotik berbasis bekatul. Teknologi Pertanian. 7(2) : 89-95. 